\title{
What Are the Key Job Functions and Critical Competencies Required for the Role of the CIO in Achieving Superior Organizational Performance?
}

\author{
Leeanne Hodgson and Michael S. Lane \\ University of Southern Queensland, Toowoomba, \\ Queensland, Australia
}

lhodgson@ozemail.com; Michael.Lane@usq.edu.au

\begin{abstract}
This research paper investigated the role of the modern CIO in terms of their key job functions and critical capabilities and competencies which are required in order for the CIO to achieve superior organizational performance for the current and future business environment. Six CIO interviews conducted by the CIO Executive Council were analysed in terms of previous literature which had identified a number of key job functions and critical capabilities and competencies for the role of the modern CIO. The findings of this research lends support to five key job functions and eighteen critical competencies which we believe are essential for the role of the CIO in current and future business environment. The findings also indicate that the CIO role is becoming increasingly strategic in driving innovation and organizational transformation and change. Hence the modern CIO needs to be a visionary strategic leader with superb communication skills and business acumen and the ability to collaborate horizontally across the core business functions and with key business partners.
\end{abstract}

Keywords: chief information officer, competencies, capabilities, IS function, IS strategy, IS/IT management

\section{Introduction}

\section{Background to Research}

The Chief Information Officer (CIO) role emerged from the 1950's as a data processing manager, and has evolved over the years to that of an executive dealing with the use of information communication technology (ICT) from a social, economic and strategic management viewpoint (Chun

Material published as part of this publication, either on-line or in print, is copyrighted by the Informing Science Institute. Permission to make digital or paper copy of part or all of these works for personal or classroom use is granted without fee provided that the copies are not made or distributed for profit or commercial advantage AND that copies 1) bear this notice in full and 2) give the full citation on the first page. It is permissible to abstract these works so long as credit is given. To copy in all other cases or to republish or to post on a server or to redistribute to lists requires specific permission and payment of a fee. Contact 0HPublisher@InformingScience.org to request redistribution permission.
\& Mooney, 2009; Stephens et al, 1992). As ICT has become critical infrastructure for most organizations, the CIO role has become increasingly important and challenging and is said to bridge a gap between the information technology group and the functional areas of an organisation and its external entities (Chun \& Mooney, 2009; Lane \& Koronios, 2007b; Stephens et al, 1992). 
CIO's today must embody the leadership characteristics and competencies of the Chief executive officer (CEO) and other senior-level executives in finding innovative ways for ICT to enable or advance the business objectives of the company to achieve superior organizational performance (SpencerStuart, 2005). Examples of ways that ICT is innovative is the use of sophisticated systems which tracks trends on customer interactions, performance of products, employee productivity and other factors. Data collected from these systems can be used to run experiments to allow management to analyse what influences shoppers decisions and customer behavior can be measured in a cheaper and more agile manner (Brynjolfsson \& Schrage, 2009). One of the most important innovative factors that have driven businesses over the last 5-t0 years has been the way that organizations share data and insights and the use of Internet has allowed for this kind of sharing. ICT is thus a major resource which can radically affect an organisation's structure, the way it serves customers and the way it communicates both internally and externally (Rockart et al, 1996).

The main purpose of this study is to consider the role of the CIO in today's business environment and the future, and to identify what capabilities and competencies are critical for the CIO role to successfully drive innovation and competition through the use of ICT in the current and future business environment.

\section{Two Main Research Questions Investigated in this Study}

This study investigates the following two research questions:-

RQ1: What are the key job functions in the role of the CIO in the current and future business environment?

RQ2: What capabilities and competencies are critical for the CIO role to be successful in driving innovation and competitiveness by leveraging Information Communications Technology in the current business environment and why?

\section{Justification for this Research}

The business environment has changed significantly in the last decade in response to globalization of modern economies and increased importance and reliance of organisations on information technology and communication (ICT). There is no doubt that ICT has become both as enabler of key business processes and as a source of competitive advantage through technological innovation for organisations. Hence increasingly the most senior IT executive, the chief information officer (CIO) in medium to large organisations has a key role to play in contributing to performance and strategic direction of an organisation. Furthermore the role of the CIO has changed significantly in the last decade in response to globalization and rapidly changing and new and emerging ICT. However there is a lack of empirical research regarding the changing role of the CIO in both current and future business environment in relation to what are key job functions and critical competencies and capabilities required for the role of the CIO.

\section{Structure of Paper}

This paper is structured as follows. First this research paper synthesizes a number of definitions of the role of the chief information officer (CIO) drawing on the existing literature with the aim of providing a definitive and current definition of the role of the CIO. Then a review of the literature on the role of the CIO and the capabilities and competencies critical for the CIO role to be successful are discussed. The research problem and issues being studied is then described and justified. Then the methodology used to analyse six interviews of CIOs to provide answers to the general research question investigated in this study, is described and justified. Next, key findings of this research in relation to the current and future role of the CIO is discussed. Finally, the con- 
clusions and implications of this research regarding the current and future role of the CIO and suggestions for future research are presented.

\section{Chief Information Officer Role - Job Functions and Critical Competencies and Capabilities \\ Role of the $\mathrm{CIO}$}

The CIO is an information systems executive whose role is deeply embedded in business organizations, helping CEOs strategize and business unit leaders to implement strategies (Chun \& Mooney, 2009; Lane \& Koronios, 2007b). As ICT has increased in importance, the CIO has gained visibility within organizations as a key contributor in formulating strategic goals. The CIO sits on the executive board and provides advice and guidance on how ICT can enable and deliver business strategies and goals (Lane \& Koronios, 2007b).

In the 1950s and 1960s the original IS manager's role was that of a technician managing a data processing service function and was seen as a relatively unimportant function to the organization (Chun \& Mooney, 2009). With the huge technological advances that occurred over the next decades, the technology management role gained in importance and influence to the point where it achieved Chief Information Officer status (Chun \& Mooney, 2009).

In the 1990s the CIO role was elevated within forward thinking firms to where CIOs began to operate as an executive focusing on business imperatives, managing Information Services (IS) executive relationships and IS development, communicating ICT value and building a sound architecture for the firm's ICT (Chun \& Mooney, 2009; Rockart et al, 1996; Stephens et al, 1992). In many studies, research showed that an increasing number of CIOs had begun to report directly to the CEO and that over half had become senior managers (Chun \& Mooney, 2009). However since the late 1990s/early 2000, there has been a number of conflicting arguments about the role of the $\mathrm{CIO}$ with some arguing that the $\mathrm{CIO}$ is obsolete while others argue that the $\mathrm{CIO}$ is the next CEO. (Chun \& Mooney, 2009; Lepore, 2000; Maruca, 2000; Rockart, 2000). The CIO was perceived to be in charge of a function that consumed major resources but offered little proof of its value to the organisation (Chun \& Mooney, 2009).

As more and more businesses rely on technology to be competitive, the CIO is the natural person to drive that process. The impact of globalization and the development of the World Wide Web have dictated major changes in ICT roles, structure and processes. Organisations have built bigger and more capable ICT organizations and the CIO has moved into the ranks of top management (Rockart, 2000; Rockart et al., 1996). No longer is the CIO driven by business, but rather is seen as also driving the business. Hence the role of the CIO has changed from that of a functional manager with line responsibility for information technology products and services, to a senior executive responsible for establishing corporate information policy standards and management control over all corporate information resources (Stephens et al, 1992). The CIO must consider the business as a whole and is responsible for aligning ICT with the business goals and leveraging ICT to achieve the strategic vision of an organization (Blair, 2005; Deloitte, 2004; Korn/Ferry International, 1998; Lane \& Koronios, 2007b).

The CIO of today is seen as a business executive first, and a technologist second (Blair, 2005; Rockart, 2000). The responsibilities for those holding the position of CIO also varies widely and in recent years there has been an evolution of what are the key roles of a CIO. Five primary roles were discussed by Lane \& Koronios, (2007b). These roles included the CIO as a (1) business strategist; (2) as an ICT strategist; (3) as a Change Agent; (4) as a Technology advocate and (5) as a Functional leader. 
As business grows and changes, it is expected that the CIO role will continue to evolve taking on more responsibility and participating in strategy formulation, whilst still handling the technology issues on a more detailed level (Lepore, 2000). First and foremost CIOs will provide technology solutions that support the overall business objectives. It is argued that the $\mathrm{CIO}$ will become the next CEO (Lepore, 2000; Blair, 2005). CIOs are evolving and developing their skills in change management and emerging as leaders of innovation, bringing ideas to the 'table', putting their end-to-end knowledge of the business to use in thinking through new technology based opportunities (IBM, 2008)

\section{Capabilities and Competencies Critical for the CIO role to be Successful}

The key to success of the CIO role is strong leadership, which entails understanding the business so that they can explain how IT will impact the business and what benefits it will demonstrate once implemented (Blair, 2005). The CIO of today looks for innovative ways for ICT to advance the business objectives of the company through technology. These value added services initiate fundamental change in business processes and strategies through the use of ICT (Chun \& Mooney, 2009; Lepore, 2000). To strategically leverage ICT to address the organisations' initiatives in the current environment, is a complex process and it takes a lot of work by the CIO to partner with other members of the senior executive team to build respect and trust (Blair, 2005; Gottschalk, 1999).

This new CIO of tomorrow will increasingly become a business management expert with a good understanding of technology, and will move into the circle of corporate planners at the highest level (Korn/Ferry International, 1998; Govender, 2008). The CIOs pivotal responsibility of aligning business and technology direction presents a number of problems in that whilst they are creating innovative business applications to help the organisation gain competitive advantage, they are still spending most of their time dealing with the daily technological problems and grappling with legacy system maintenance (Gottschalk, 1999). Often the need to maintain existing ICT infrastructure and legacy systems severely restricts the $\mathrm{CIO}$ in their role of driving business innovation in organisations through the use of ICT.

It is the increasing complexity and business focus of the CIO role that has caused many organisations to look outside the organization for the right qualifications for a CIO. Characteristics such as professional background, education and current length of tenure, as well as leadership qualities and relationship building skills are being sought in the future CIO (Deloitte, 2004; Gottschalk, 1999). It is the objective of this research to explore the roles and responsibilities of the modern day $\mathrm{CIO}$ to determine the current and future competencies required for the role of the CIOs.

Lane \& Koronios (2007) identified 16 competencies for the role of the CIO from the existing literature which were ranked in accordance with their importance. All but one of the competencies were considered important by CIOs who participated in the study plus another seven competencies were added in this study. In summary, this study showed that the CIO has become more business focused and strategic. The primary role of business strategist and IT strategist and the higher levels of knowledge of the business now dominate the role of the CIO, whereas specific practical knowledge of technology has become less important in the role (Lane \& Koronios, 2007). It is the alignment of ICT with other functions of the business or management of the ICT architecture that was seen as the critical competency for the CIO role rather than the actual management of every day data processing. The critical competencies will be further explored when analyzing the six interviews in this study. 


\section{Methodology}

\section{Research Design}

Six interviews were conducted by the CIO Executive Council who selected six CIOs from different organizations who are members of the CIO Executive Council to determine what the key job functions in the role of the CIO in the current and future business environment as well as the capabilities and competencies critical for the CIO role to be successful. The interviews involved asking the respondents to answer open ended questions about the role of the $\mathrm{CIO}$, its evolution and potential role in the future. The person conducting the interviews was the general manager of the CIO Executive Council. The CIOs were interviewed on what they believed were core functions of the CIO role today and what competencies and capabilities are critical for successful CIOs. In this research paper we analysed these six qualitative interviews conducted by the CIO Executive Council using an interpretative approach. Qualitative data provides researchers with rich information, are based in 'real-world' concerns, have intuitive appeal to non- researchers, and allow the researcher to explore in deep and meaningful ways the phenomena under study. The purpose of this study was to investigate the role of CIOs and the key job functions and critical competencies and capabilities of the six CIOs in these roles. The qualitative analysis of these six interviews in depth was considered an appropriate approach to address and provide some answers to the two main research questions of this study.

In the previous section the key job functions of the $\mathrm{CIO}$ role were identified and categorized from the existing literature. The CIO interviews were analysed for common themes that related to these categories, and job functions and responsibilities of the CIO in the current and future business environment. Four categories identified by Chun and Mooney, (2009) were used to compare the results from the interviews. The CIO interviews were further analysed for common themes relating to capabilities and competencies of the $\mathrm{CIO}$ and were categorized according to the questions asked. These were then compared to the competencies identified by Lane \& Koronios (2007).

\section{Method of Data Analysis}

This study used content analysis as a method of qualitative analysis. This method allowed for in depth qualitative data from in depth interviews of CIOs from six organisations to be analysed in an interpretative manner. The 'what' research questions being studied are exploratory and result in large amounts of contextual data. Content analysis allows for large volumes of data to be categorised by recurring themes and concepts (Yin, 1994).

The analyses of the six interviews was conducted in Excel spreadsheets which allowed for the detailed responses of each interview to be separately analysed and then the relevant responses from each interview were compared and summarized across the six interviews. The final results were derived from common responses in the interviews which related to the research questions found in all or the majority of the interviews. Responses to these questions were presented in a spreadsheet which detailed the common interview responses which were related to our research questions; and the common themes in the responses identified which were then split into categories and sub categories. The frequency that these categories occurred in each interview, were presented on the final spreadsheet. The use of Excel allowed for the data analysis to be conducted in a rigorous manner and for the interpretation of qualitative data to be cross checked by each of the researchers in this study. 


\section{Results of Data Analysis of six CIO Interviews}

Table 1 presents a summary of the demographics of the six CIOs interviewed and their organisations. These six CIO interviews represent a wide range of industries from higher education through to Media and individual experiences of the CIO role from 4 years through to 12 years and 17 through to 30 years experience in ICT.

Table 1 Demographics of each case organization and CIO background

\begin{tabular}{|c|c|c|c|c|c|c|}
\hline & Case 1 & Case 2 & Case 3 & Case 4 & Case 5 & Case 6 \\
\hline Name of CIO & Male & Male & Male & Female & Male & Female \\
\hline $\begin{array}{l}\text { Type of organi- } \\
\text { zation industry } \\
\text { sector }\end{array}$ & $\begin{array}{l}\text { Higher Educa- } \\
\text { tion }\end{array}$ & Electronics & $\begin{array}{l}\text { Energy } \\
\text { Retailer }\end{array}$ & $\begin{array}{l}\text { Financial } \\
\text { Services }\end{array}$ & $\begin{array}{l}\text { Retail prop- } \\
\text { erty manage- } \\
\text { ment }\end{array}$ & $\begin{array}{l}\text { Global secu- } \\
\text { rity and de- } \\
\text { fense systems }\end{array}$ \\
\hline $\begin{array}{l}\text { Number of } \\
\text { years as CIO in } \\
\text { this organiza- } \\
\text { tion }\end{array}$ & 4 years & 6 years & 5 years & 12 years & 3 years & 8 years \\
\hline $\begin{array}{l}\text { Years of experi- } \\
\text { ence in ICT }\end{array}$ & 17 years & 20 years & Unknown & 30 years & 20 years & 28 years \\
\hline $\begin{array}{l}\text { Formal back- } \\
\text { ground and } \\
\text { education }\end{array}$ & $\begin{array}{l}\text { Information } \\
\text { Technology, } \\
\text { Sociology and } \\
\text { anthropology }\end{array}$ & $\begin{array}{l}\text { Information } \\
\text { Technology }\end{array}$ & Engineering & Banking & $\begin{array}{l}\text { Business Fi- } \\
\text { nance and } \\
\text { Computing }\end{array}$ & $\begin{array}{l}\text { Software en- } \\
\text { gineering and } \\
\text { project man- } \\
\text { agement }\end{array}$ \\
\hline $\begin{array}{l}\text { Part of Execu- } \\
\text { tive manage- } \\
\text { ment team }\end{array}$ & Yes & Yes & Yes & Yes & Yes & Yes \\
\hline
\end{tabular}

The analyses of the six CIO interviews found four dominant roles of the $\mathrm{CIO}$ in the current and future business environment which were (1) Leadership; (2) Process improvement and innovation; (3) Relationship building and (4) Value add services - strategic leadership. There was an additional role in the current business environment of technology management. However the role of the CIO is evolving in response to the changing business environment and technological innovation, which is seeing information technology merging with telecommunications. Hence the role of the CIO is moving away from solely focusing on technology management and moving towards integrating technology into all parts of the business to drive the strategic direction of the organization.

\section{Key Job Functions of $\mathrm{ClO}$ in Current and Future Business Environment}

These job functions were further broken down into sub categories which represented the competencies and capabilities required of the CIO in the current business environment. Two main research questions focused on the major changes that the CIO role has experienced and what the CIO role will entail in the future.

The analysis found that the key job function in the role of the CIO in the current business environment has evolved from one of a utility service manager to one that has moved into the sphere of enabling and value adding to the core business through the use of ICT. The analysis has summarized the key job functions in the role of the CIO into five key categories for the current business environment and into four key categories for the future business environment (see Table 2). 


\section{Table 2 Key Job Functions in the role of the CIO}

\begin{tabular}{|c|c|}
\hline $\begin{array}{l}\text { Current business envi- } \\
\text { ronment }\end{array}$ & $\begin{array}{l}\text { Future business environ- } \\
\underline{\text { ment }}\end{array}$ \\
\hline \multicolumn{2}{|l|}{ Technology based } \\
\hline Leadership & Leadership \\
\hline $\begin{array}{l}\text { Process improve- } \\
\text { ment/innovative }\end{array}$ & $\begin{array}{l}\text { Process improve- } \\
\text { ment/innovative }\end{array}$ \\
\hline Relationship Building & Relationship Building \\
\hline $\begin{array}{l}\text { Value add services - stra- } \\
\text { tegic leader }\end{array}$ & $\begin{array}{l}\text { Value add services - strate- } \\
\text { gic leader }\end{array}$ \\
\hline
\end{tabular}

Our analysis of all of the interviews identified that the CIO key job functions were leadership, setting the strategic direction of the organization and building relationships with colleagues, clients and external customers. Four of the six cases identified the role of the $\mathrm{CIO}$ as leveraging ICT to improve business processes and to drive innovation through the development of new products and markets. The functions of the roles identified in the Lane and Koronios (2007a) study were supported for the Strategist role, Change agent and Leadership roles. The technology advocate, even though supported by one case study, was not a dominant function across the interviews in relation to what the key job functions are for the CIO of today and the future. Relationship building (or human resource management as another term) was identified as a critical competency of the CIO role in the Lane and Koronios (2007a) study and which was further supported by the key findings of this research.

The results of our data analyses also provide further support for the IBM (2008) survey which found four similar competency areas in the role of the CIO. These were leadership, business strategy and process, innovation and growth and organisation and talent management (which also falls under the category of relationship building with a broader focus) (IBM, 2008).

Our data analyses indicate that the key functions of the CIO of the future will not focus on technology management, but rather incorporate ICT into all aspects of the organisation which will drive its core business and its strategic direction. The CIO plays a major role in senior leadership discussions around the formulation and implementation of business strategy (Govender, 2008). The CIO's role is seen as leading the 'value adding' IS function which plays a critical role in the implementation of organizational strategy and is no longer just a cost centre. Increasingly technology management role of the IS function is handled by a subordinate of the CIO such as a technology manager. CIO of Chevron Louie Ehrlich noted that he has now decreased his supervision of technical systems to just $10 \%$ of his time, instead delegating those responsibilities to a subordinate.

\section{Critical Competencies and Capabilities Essential for CIO Role}

The competencies and capabilities which we identified in our analysis of the $6 \mathrm{CIO}$ interviews to be critical for the CIO to be successful in his/her role, have been mapped to five key job functions in Table 3. Eighteen (18) competencies were identified previously as being considered important by the CIO (Lane \& Koronios, 2007). In Table 3 we indicated which of these competencies were discussed in the six CIO interviews and considered to be important. The key competencies that were acknowledged in the majority of the six case interviews were (1) good communicator as a leader; (2) collaboration/co-operative decision making as part of relationship building; 
and (3) as a strategic leader, having a good business knowledge and being able to contribute to the profit of the organization by leveraging ICT to value add in the current business environment.

Table 3 Key job functions and relevant capabilities and competencies critical for CIO role

\begin{tabular}{|l|l|c|}
\hline \multicolumn{1}{|c|}{ Category - Job Function } & \multicolumn{1}{c|}{\begin{tabular}{c}
\multicolumn{1}{c|}{ Competency and } \\
Capabilities
\end{tabular}} & Interview No \\
\hline 1) Technology based & Data processing manager & $3,5,6$ \\
\hline 2) Leadership & Have clear goals & $1,2,6$ \\
\hline & Be collaborative & 1,5 \\
\hline & Good communication & $1,2,3,4,5,6$ \\
\hline $\begin{array}{l}\text { 3) Process improvement / } \\
\text { innovation }\end{array}$ & Democratic style & 1 \\
\hline & $\begin{array}{l}\text { Innovative through new products and mar- } \\
\text { kets }\end{array}$ & 3,6 \\
\hline 4) Relationship Building & Cross functional stewardship & 1,2 \\
\hline & Accountability & 3 \\
\hline & Build trust and getting consensus & $4,5,6$ \\
\hline & Collaborative -co-operative decision making & $2,4,5,6$ \\
\hline & Being able to work with others & 2 \\
\hline $\begin{array}{l}\text { 5) Value add services }- \\
\text { strategic leader }\end{array}$ & Build team spirit & $4,5,6$ \\
\hline & Understand business & $1,3,5,6$ \\
\hline & Process integration - strategic direction & $1,2,3$ \\
\hline & Being able to contribute to profit & $2,4,5,6$ \\
\hline & Good planning skills & 6 \\
\hline & Decision making skills & $1,3,6$ \\
\hline & Skills for customer service & 2,4 \\
\hline
\end{tabular}

The analysis of the competencies of a strategic leader supports seven of the 16 competencies found in the Lane and Koronios (2007a) study: leadership; strategic planning; business alignment \& innovation with ICT; human resource management; managing business relationships with ICT; business process management; managing knowledge/intellectual capital. The analysis also supports five of the 10 essential capabilities found in the study by Deloitte (2004) of the modern CIO. These were: company goal - grow shareholder value; collaboration; business integration; growing talent - building team spirit; and skills for customer service.

Communication was seen by all of interviewees as the most important competency of the CIO. Communication was defined as being able to communicate to all levels of the organization, having a forum for sharing of ideas and engaging people in communication and process of change. Open communication allows for consensus and buy in on strategic decisions at all levels of the organisation.

For the CIO to be successful in driving innovation and competitiveness, the role has seen the $\mathrm{CIO}$, moving away from the traditional role of the data processing manager providing a utility service, to one that provides more value adding services to the organisation. The CIO in the current business environment is required to have a good understanding of the business, and requires new skills as a strategic and business leader to leverage ICT to drive the organization to improve its performance and efficiency. These skills are required so the CIO can understand and explain to the organization how IT can assist management in making strategic decisions to meet the business objectives (Ebaugh, 2005). Also, for an organization to keep its competitive advantage, it requires a solid business-IT architecture to integrate alignment between processes, systems, data and infrastructure. This requires clear leadership and diligent planning and the CIO is the natural person to 
drive this process (Deloitte, 2004; Lepore, 2000). Given the increasing importance of ICT in organizations as the key to the future business success and growing market share, the skills required of the CIO helps manage growth and development of business in organisation.

\section{Limitations and Future Research}

We acknowledge that the results and findings of our study need to be treated cautiously. Our findings are limited to the analysis of a small number of interviews which were conducted by another party - the CIO Executive Council which has ready access to a number of high profile CIOs in large organisations. An independent study with larger number of interviews with a 360 degree view of the CIO role followed by a large quantitative survey would provide more reliable findings and add more validity to the analysis. The questions asked were not consistent across the interviews. The use of open ended questions resulted in very broad answers in the interviews therefore there is a degree of subjectivity used in interpreting the empirical data analysed in this study. Further work should focus on developing a theoretical base for understanding the role of the Modern CIO and how it is evolving in response to changing business needs and rapidly evolving and emerging new technologies. There is also a need to provide a more quantifiable understanding and rating of each of the key job functions of the modern CIO and the critical competencies required for the role.

\section{Conclusions and Implications}

This study provides evidence which lends support to determining what are the key job functions in the role of the CIO in the current and future business environment. It also identifies capabilities and competencies critical for the CIO to be successful in driving innovation and competitiveness by leveraging ICT in the current business environment and explains why these are important.

The evidence presented in the results section shows that the modern CIO role has moved away from the traditional technology management role and moved towards a more strategic role. To be successful, the CIO needs a good understanding of the business as a strategic leader, and needs to have good communication skills at all levels in the organisation and be able communicate effectively with business clients. The CIO needs to understand the business at all levels and be able to collaborate with others as this is critical for delivery and managing the ICT systems and infrastructure as ICT now permeates all level of organizations.

\section{References}

Blair, R. (2005).The Future of CIOs. Health Management Technology, 26(2), 58-59. Retrieved from www.healthmgttech.com

Chun, M., \& Mooney, J. (2009). CIO roles and responsibilities: Twenty-five years of evolution and change. Information \& Management, 46, 323-334.

Deloitte. (2004). CIO 2.0: The changing role of the chief information officer. Deloitte. Retrieved $18^{\text {th }}$ September, 2009, http://www.deloitte.com/dtt/cda/doc/content/CIO2sp.pdf

Gibbs, G. R., \& Taylor, C. (2005). How and what to code. Retrieved from http://onlineqda.hud.ac.uk/Intro_QDA/how what to_code.php

Gottschalk, P. (1999). Strategic management of IS/IT functions: the role of the CIO in Norwegian organizations, International Journal of Information Management, 19, 389-399.

Govender, B. (2008). The Changing Role of CIOs. SiliconIndia Magazine, 30-31. Retrieved from www.siliconindia.com

IBM. (2008). The CIO profession: Leaders of change, drivers of innovation. Retrieved $11^{\text {th }}$ September, 2009, from http://www.cioleadershipcenter.com/docs/DOC-1206 
Korn/Ferry International. (1998). The changing role of the chief information officer. Retrieved $21^{\text {st }}$ November 2005, www.kornferry.com/Library/ViewGallery.asp? $\mathrm{CID}=308$ \&LanguageID=1\&Region! $\mathrm{D}=23$ >

Lane, M.S., \& Koronios, A. (2007a). Critical competencies required for the role of the modern CIO. $18^{\text {th }}$ Australasian Conference on Information Systems, 5-7 Dec. Toowoomba, Australia

Lane, M.S., \& Koronios, A. (2007b) Determining key technology and management issues for CIOs deemed to be problematic and suffering from performance gaps, Paper presented to $1^{\text {st }}$ International Conference of ICT Innovation and Application

Lepore, D. (2000).Perspectives: Are CIOs obsolete? Harvard Business Review, March-April, 56.

Maruca, R. F. (2000). Are CIOs obsolete? Harvard Business Review, March-April, 5.

Rockart, J. (2000). Are CIOs obsolete? Harvard Business Review, March-April, 57.

Rockart, J. E., Earl, M. J., \& Ross, J.W. (1996). Eight imperatives for the new IT organization. Sloan Management Review, Fall.

Ryan, B. (2009). Techniques to identify themes in qualitative data. Retrieved from www.analytictech.com/mb870/Readings/ryan-bernard techniques to identify themes

SpencerStuart. (2005). The evolving role of the chief information officer. Retrieved $12^{\text {th }}$ March 2010 from http://content.spencerstuart.com/sswebsite/pdf/lib/Evolving_Role of the CIO Jun05.pdf

Stephens, C.S., Ledbetter, W.N, Mitra, A., \& Ford, F.N. (1992). Executive or functional manager? The nature of the CIO's job. MIS Quarterly, Dec, 449-466

Yin, R. K. (2009). Case study research: Design and methods (4th ed.). Los Angeles: Sage.

\section{Biographies}

Leanne Hodgson is a Chartered Accountant with over 20 years work experience in Accounting/Management, IT implementations, Business Analysis and Training. Throughout her career, Leeanne has been a major player in a number of computer implementations using various systems, such as JD Edwards, Sun Systems, Oracle and SAP. She has also consulted in Business Analyst and Data Migration Project Management Roles as well as trained and wrote training programmes for the implementation of Oracle in a large publicly listed company in Australia. Leeanne is enrolled in a PHD at USQ. She trains part time for the Institute of Chartered Accountants for clients in Audit/Tax as well as for the CA programme in all modules. Leeanne holds a Degree in Administration - majoring in Accounting and Human Resource Management from Griffith University and holds a Graduate Diploma in Finance and Investment.

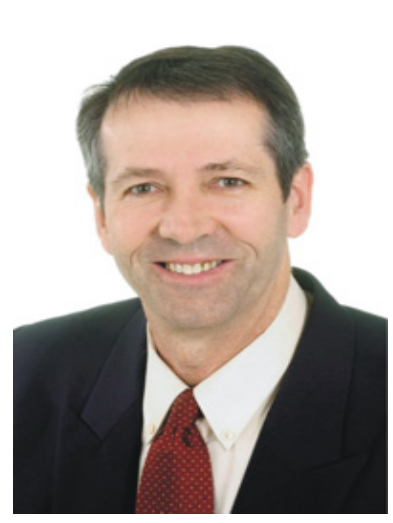

Dr Michael Lane is a Senior Lecturer and member of the School of Information Systems in the Faculty of Business. He has a PhD in Information Systems from the University of Southern Queensland. Michael's research is concentrated in the area of strategic management of ICT including sustainable use of ICT, the changing role of chief information officer (CIO), information security management, wireless and mobile computing. 